\title{
Impact of on-grid solar energy generation system on low voltage ride through capability
}

\author{
Mohammad Ahmad Shawqi ${ }^{1}$, Mokhtar Hussien Abdallah' ${ }^{2}$, Ibrahim Ahmed Nassar ${ }^{3}$ \\ ${ }^{1}$ Research and Planning Department, Ministry of Electricity and Renewable Energy, Cairo, Egypt \\ ${ }^{2}$ Developing Performance and Political Communication Unit, Ministry of Electricity and Renewable Energy, Cairo, Egypt \\ ${ }^{3}$ Electrical Power and Machines Engineering Department, Al Azhar University, Cairo, Egypt
}

\begin{abstract}
Article Info
\section{Article history:}

Received Jul 14, 2021

Revised Jan 24, 2022

Accepted Jan 31, 2022

\section{Keywords:}

Genetic algorithm

Grid connected

Low voltage ride through

MATLAB simulation

Solar energy generation

ABSTRACT

This paper represented a control strategy for photovoltaic (PV) system, this control strategy was referred to as a low voltage ride through (LVRT), it had been achieved by using three phase (3-PH) (PV) grid-connected system, where this paper discussed the way to achieve maximum output active power from the solar system, while the solar system remained connected to the grid with voltage decreasing controller techniques and this was valid until certain amount of voltage decreasing which was clarified in the results. The main goal of low voltage ride through depended on injecting reactive power to the grid, amount of the injected reactive power depended on regulations of the grid code using the control of the inverter and the strategy depended on the grid voltage drop amount. MATLAB simulation had been used to achieve what was mentioned above, which led to present various cases of achieving maximum output active power with grid voltage drops by using conventional proportional integral (PI) control of the inverter. Finally, another control method, which was proportional integral genetic algorithm (PI-GA), had been used to improve value of the generated output active power.
\end{abstract}

This is an open access article under the CC BY-SA license.

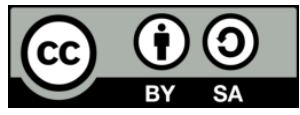

\section{Corresponding Author:}

Mohammad Ahmad Shawqi

Research and Planning Department, Ministry of Electricity and Renewable Energy

Abbasia Square, Cairo, Egypt

Email: wild_shakshak@yahoo.com

\section{INTRODUCTION}

Recently, the lack of conventional fuels and pollution has become an important issue because it causes global climate change and a shortage of energy resources [1], [2]. Consequently, the global directed towards using green energy resources [3], such as wind, solar, geothermal and biomass [4], [5]. To achieve the needed requirement and decrease the problems attached with the lack of conventional fuels and the polluted atmosphere and many studies have been performed for renewable energy development [6], [7].

There is a big problem faces the regulatory entities which is the bad impact on the grid while connecting generation systems especially when the connected systems become large [8], [9]. Therefore, many countries regulate a code for the grid to qualify this negative impact. These regulations vary from country to country [10], [11]. Generally, these regulations clarify that photovoltaic (PV) systems must remain connected and operated for a specific time while cases of voltage drop in the grid [12], and supporting this grid with the required reactive current [13], [14]. The definition of this requirement, called low voltage ride through (LVRT), it is very important to avoid the blackouts of the grid [15], [16].

Depending on the voltage drop value, the requirements of LVRT are different regarding the duration of the fault and the quantity of the reactive power injected [17], [18]. These requirements to ensure the PV 
system remains connected to the grid and operated when the grid's voltage decreases by supplying the grid with the required reactive current in the specified voltage range and supporting the grid also with the maximum output power generation [19]-[22], It means, in case there is a drop in the voltage of the grid, the LVRT strategy determines the required injected reactive currents according to the amount of voltage decreasing of the three-phase grid. Where, the control box of (PV) inverter has the main role in enhancing the system performance [23]. It is very necessary for put grid-code regulations, determining The LVRT requirement [24]-[26].

The advanced growth in renewable energy sources pushes the distribution entities to put and update the renewable energy grid connected code to get the maximum output power generated from it without any bad impact on the grid. Egypt is one of the countries that diversify various techniques to introduce renewable energy technologies and update the grid generation, where, a big plan was made to spread grid connected PV small scall systems, this plan targeted one thousand roof top system in its first phase [27]. In this paper, the values of the solar system active power, reactive power, active currenct, reactive current and the percentage of total harmonic distortion (THD \%) for current had been checked. Finally, we concluded that there is an impact of grid connected solar energy generation system on LVRT capability.

\section{RESEARCH METHOD}

\subsection{3-PH ON-GRID SOLAR ENERGY SYSTEM}

Figure 1 represents 3-PH on-grid solar energy generation system configuration, the PV system performance was studied while controlled it by conventional PI control with various solar irradiance. The solar system consists of solar array, converter, DC connection, inverter and filter. The converter was adjusted with maximum power point tracking (MPPT) strategy to ensure that the PV system generates maximum power at all times. and the inverter transfers the produced active and reactive power to the grid and the PV system connected to (IEEE 9 Buses) from Bus 2 and Figure 2 represents the three-phase grid. Table 1 represents the parameters of the 3-PH on-grid solar energy system. Figure 3 represents the power characteristics of the solar array

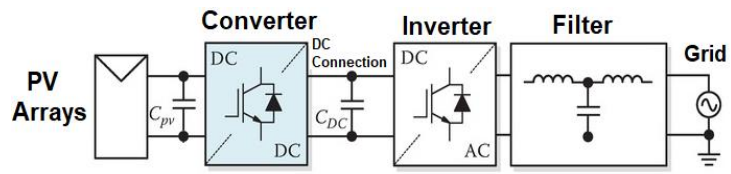

Figure 1. 3-PH on-grid solar energy generation system

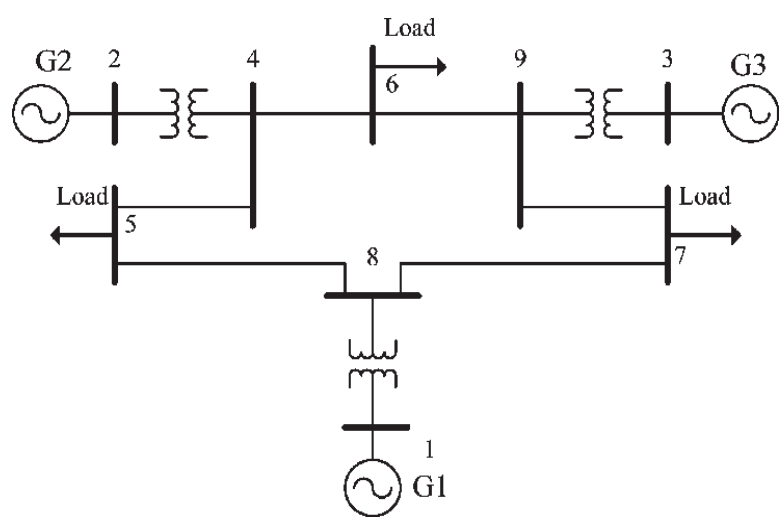

Figure 2. (IEEE 9 Buses) three-phase grid

Table 1. 3-PH on-grid solar energy system parameters

\begin{tabular}{lc}
\hline \multicolumn{1}{c}{ Parameter } & Magnitude \\
\hline Grid's Frequency & $50 \mathrm{~Hz}$ \\
Switching frequency of the converter and the inverter & $5 \mathrm{KHz}$ \\
Inductance of (solar system reactor-filter reactor) & $(0.1-10) \mathrm{mH}$ \\
Capacitance of (solar system capacitor - DC connection capacitor) & $(100-200) \mu \mathrm{F}$ \\
\hline
\end{tabular}


The model consists of 20 modules each module active power is $305 \mathrm{~W}$ and the module is called sunpower (American brand with efficiency 22\%). The solar array contains two strings, each string contains ten modules in series connection and the two strings are in parallel connection with total active power $6.1 \mathrm{~kW}$. Table 2 represents the specifications for 1 module of the solar array.

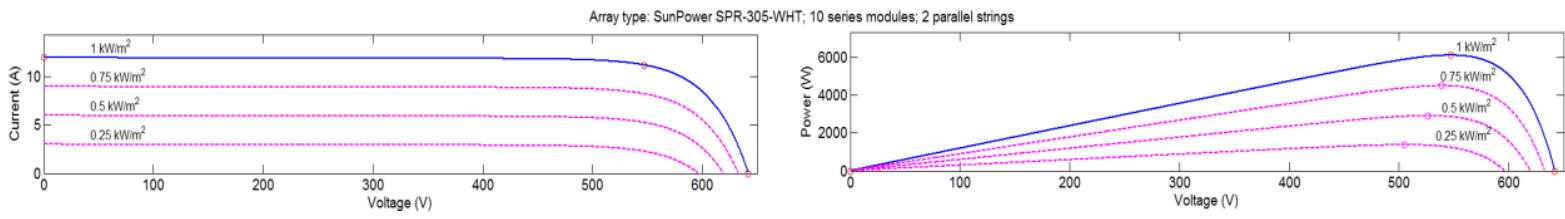

Figure 3. Power characteristics of the solar array

Table 2. Specifications for 1 module of the solar array

\begin{tabular}{lc}
\hline \multicolumn{1}{c}{ Specifications } & Magnitude \\
\hline cells connected in series & 96 \\
voltage of maximum power point & 54 Volt \\
current of maximum power point & $5.6 \mathrm{Amp}$ \\
open circuit voltage & $64 \mathrm{Volt}$ \\
short circuit current & $6 \mathrm{Amp}$ \\
\hline
\end{tabular}

\subsection{Low voltage ride through control strategy}

The LVRT control strategy appears when the voltage of the grid decreases, then reactive power injects in the grid side as a react of the LVRT control strategy, the reactive current $\left(I_{d}\right)$ required for injecting reactive power into the grid side is determined according to the LVRT requirement depending on rate of the decreased voltage. In addition, maximum power transfers from solar arrays to the grid during the voltage decreasing period and the active current which responsible to produce maximum active power is calculated by (1).

$$
\mathrm{I}_{\mathrm{q}}=\sqrt{\left(\mathrm{I}^{2} \text { rating }-\mathrm{I}^{2} \mathrm{~d}\right)}
$$

Where: $\left(I_{d}\right)$ is the reactive current of the solar system, $\left(I_{q}\right)$ is active current of the solar system and $I_{\text {rating }}$ is the rated current generated by solar system.

\subsection{Inverter control}

The control of the inverter consists of two cycles (active and reactive current-DC voltage). The first one is the internal cycle that controls active and reactive currents amount as shown in Figure 4. The second one is the external cycle that controls DC voltage of the inverter as shown in Figure 5.

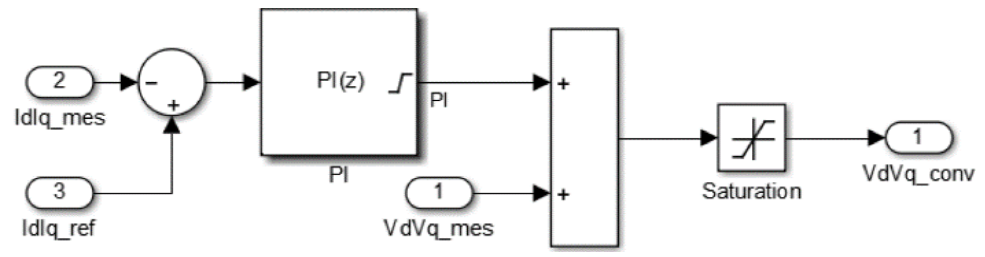

Figure 4. Active and reactive current controller

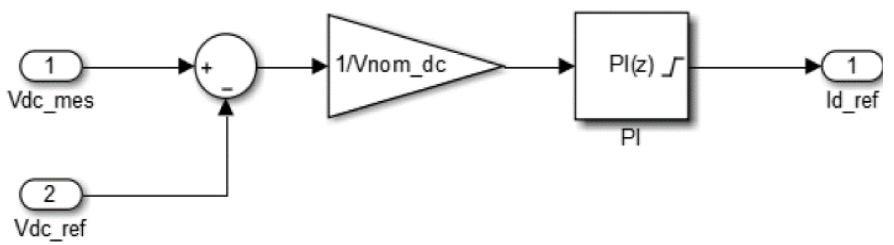

Figure 5. DC voltage controller 


\section{RESULTS AND DISCUSSIONS}

Matlab simulation software has been used in this paper as shown in Figure 6, The simulation was done within changes of the solar system sun irradiance to test the system response, $\mathrm{K}_{\mathrm{P}} \& \mathrm{~K}_{\mathrm{i}}$ of PI current regulator are 9.7 and 2405 respectively, $\mathrm{K}_{\mathrm{P}} \& \mathrm{~K}_{\mathrm{i}}$ of PI DC voltage controller are 7 and 800 respectively, DC voltage is $620 \mathrm{~V}$, analysis of the results was made by changing the nominal voltage of the PV system within (0-3) second and the studying strategy in this section is to follow up the output active and reactive power, active and reactive current and (THD\% for current) curves while changing (decreasing) the voltage of the three-phase grid. Figure 7 shows the irradiance of our simulation, where it changes from $1000 \mathrm{~W} / \mathrm{m}^{2}$ to $500 \mathrm{~W} / \mathrm{m}^{2}$ at then back again to $1000 \mathrm{~W} / \mathrm{m}^{2}$.

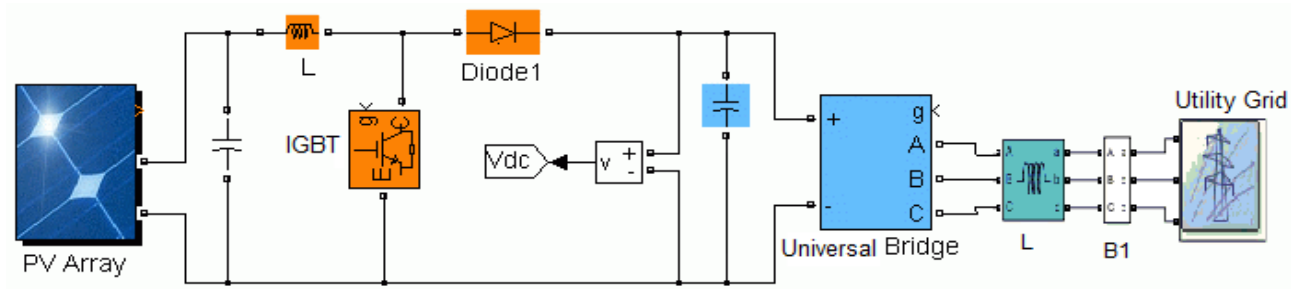

Figure 6. On-grid solar energy system MATLAB simulation

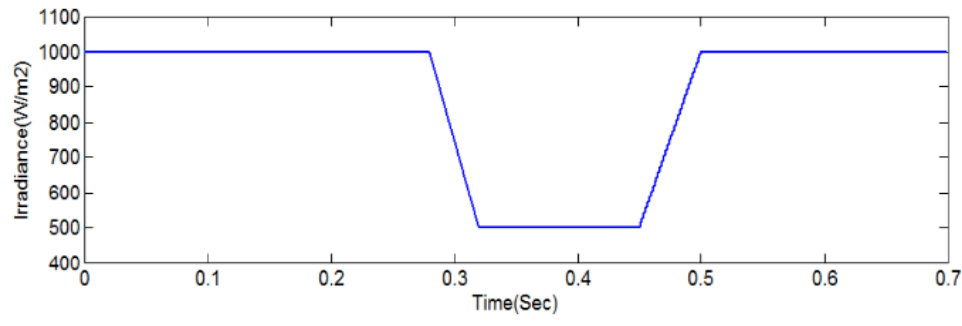

Figure 7. Used irradiance $\left(\mathrm{w} / \mathrm{m}^{2}\right)$

\subsection{Output results at 3-PH voltage equal 1 P.U}

Figures 8, 9, 10 and 11 shows the output active and reactive power, output active current and reactive current and (THD \% for current) of the on-grid solar system. It was noted that magnitude of the output active power generated from the solar system at maximum value of irradiance is $5.9 \mathrm{~kW}$ and the output reactive power is zero KVAR \{reactive current $\left(\mathrm{I}_{\mathrm{d}}\right)$ is zero \} and (THD \% for current) within limit (less than $0.5 \%)$.

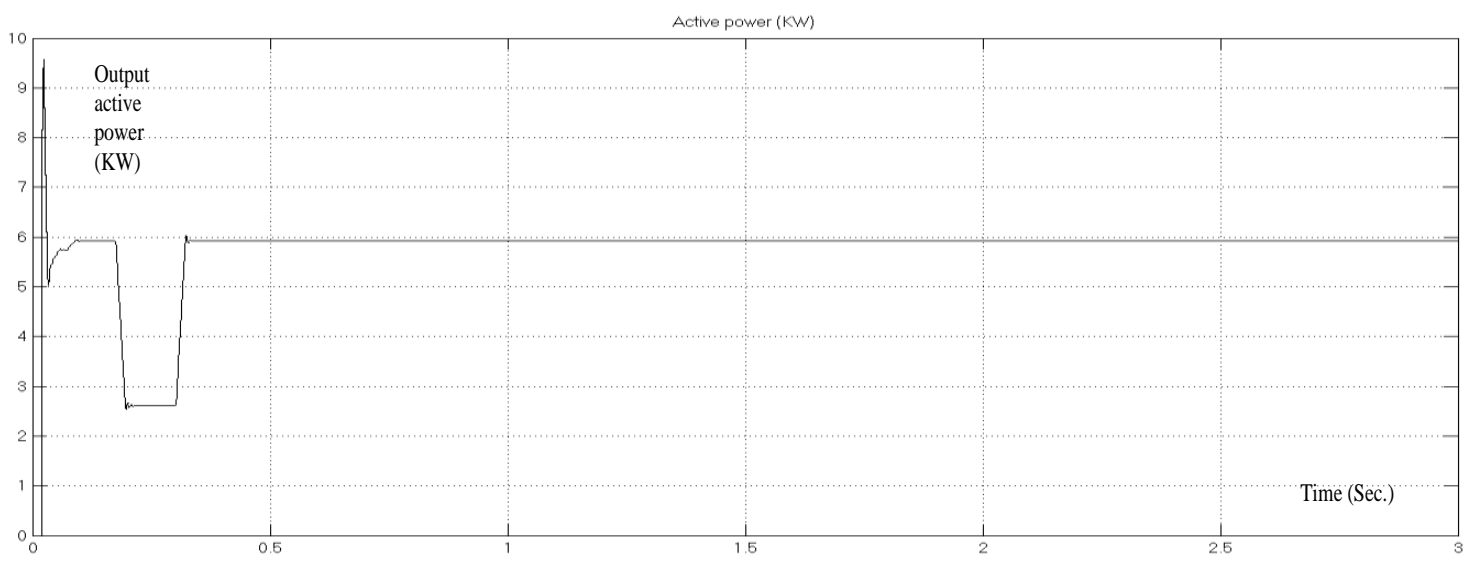

Figure 8. Output active power $(\mathrm{kW})$ 


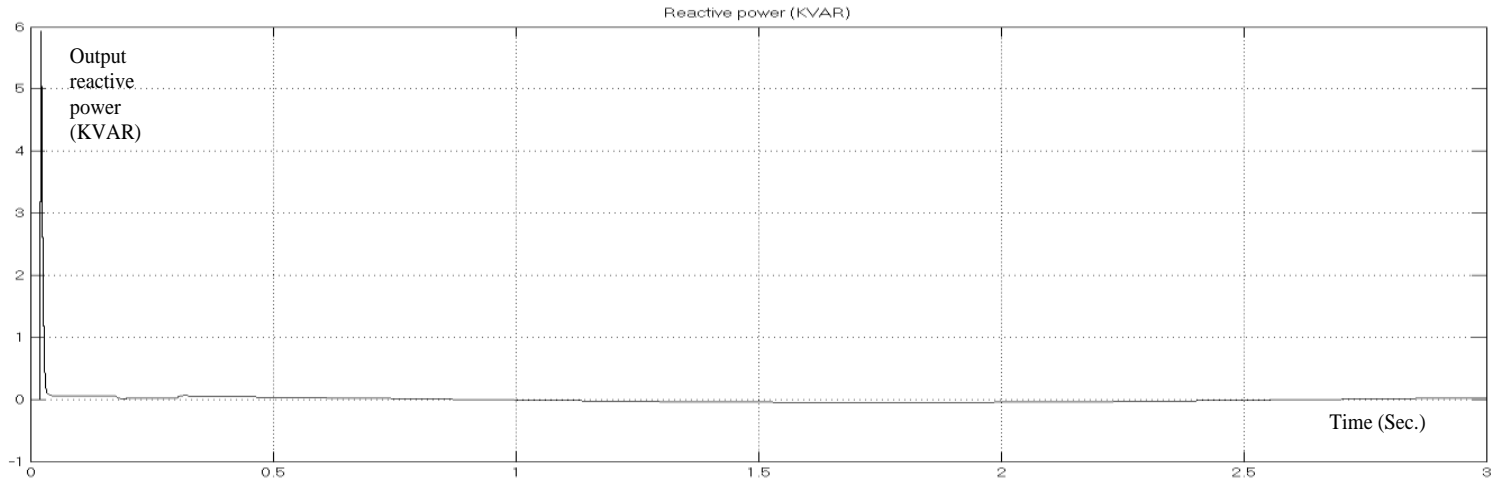

Figure 9. output reactive power (KVAR)

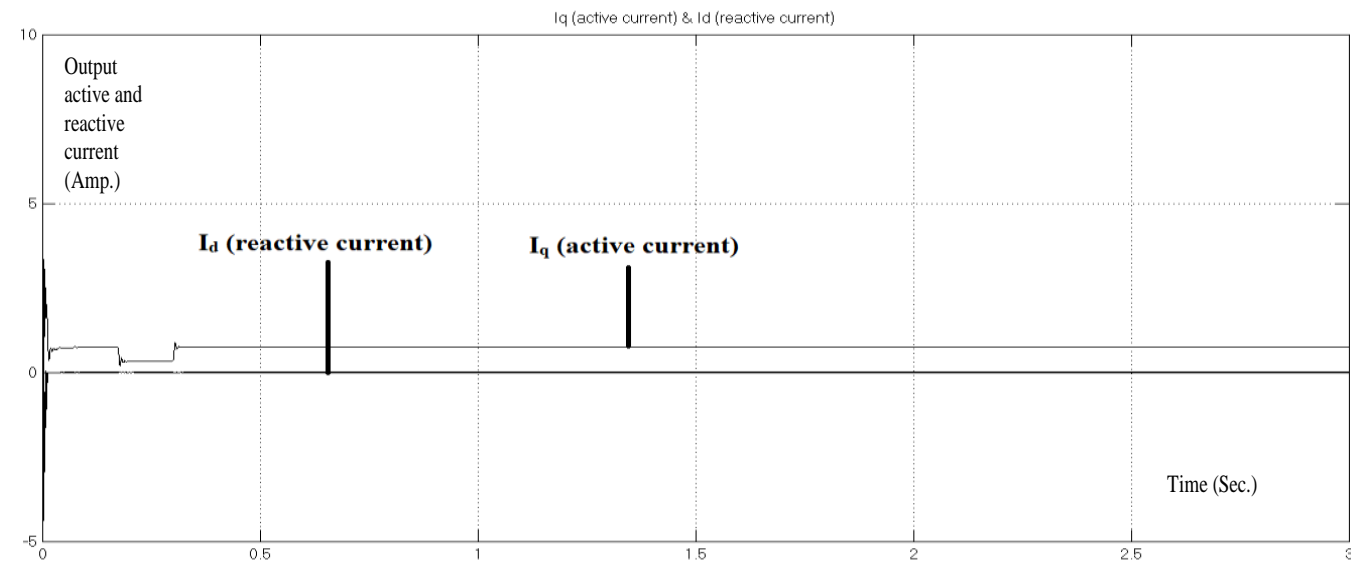

Figure 10. Output $\mathrm{I}_{\mathrm{q}}$ (active current) \& $\mathrm{I}_{\mathrm{d}}$ (reactive current

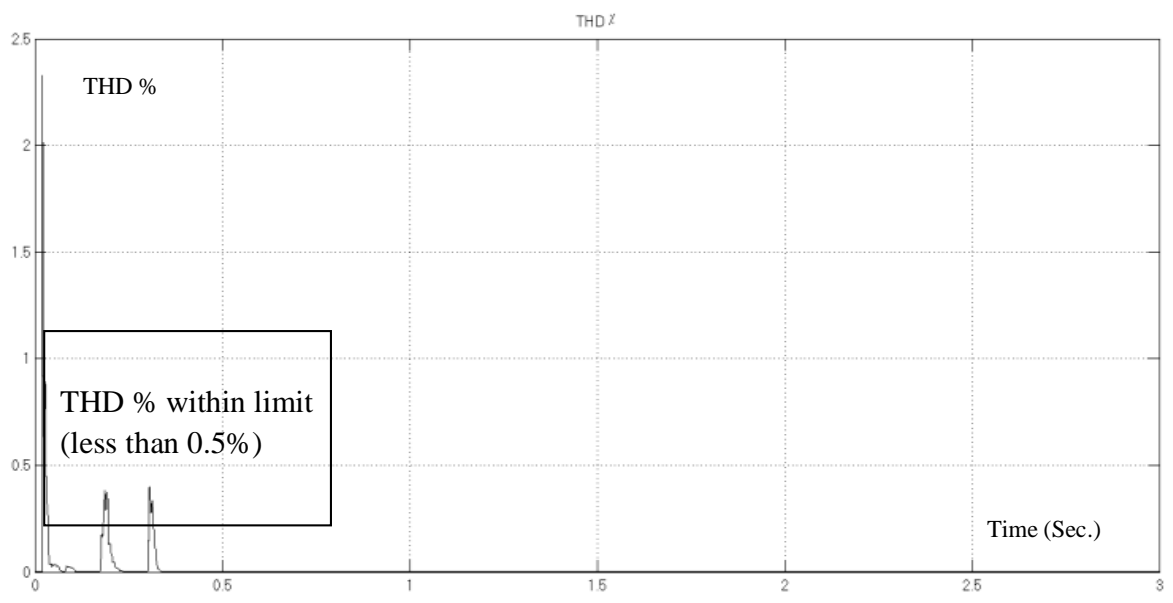

Figure 11. THD \% for current

\subsection{Output results at 3-PH voltage equal 0.8 P.U}

Figures 12, 13, 14 and 15 shows the output active and reactive power, output active current and reactive current and (THD \% for current) of the on-grid solar system. It was noted that magnitude of the output active power generated from the solar system at maximum value of irradiance is $5.9 \mathrm{~kW}$ and the output reactive current $\left(I_{d}\right)$ increased comparing to the previous case which lead to an increase in output reactive power curve comparing to the previous case, and (THD \% for current) within limit (less than $0.5 \%$ ). 


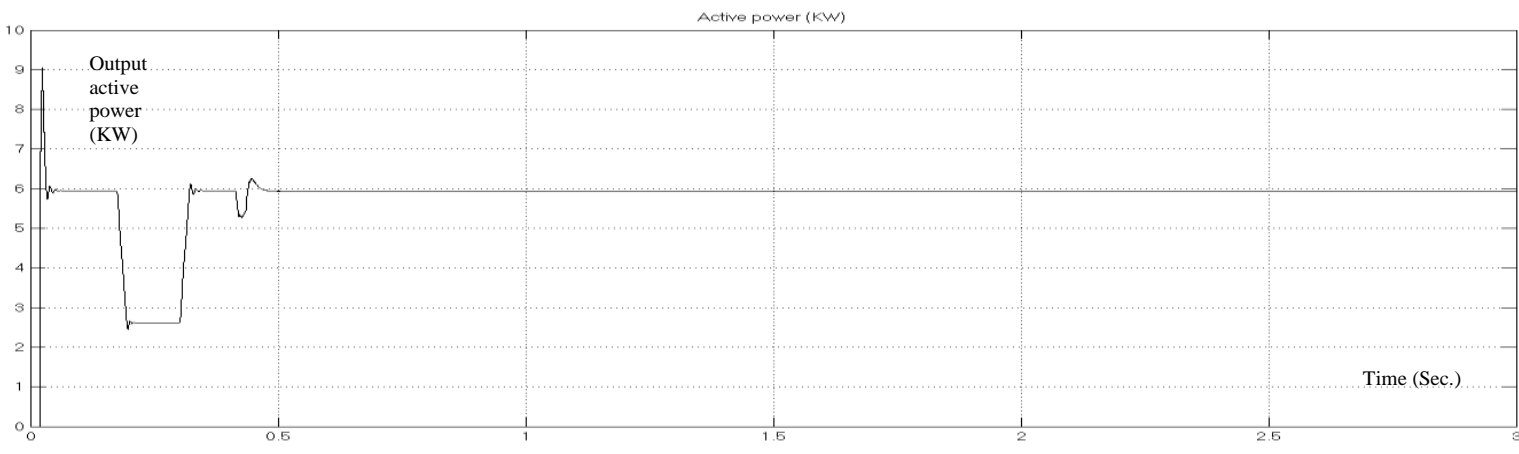

Figure 12. Output active power

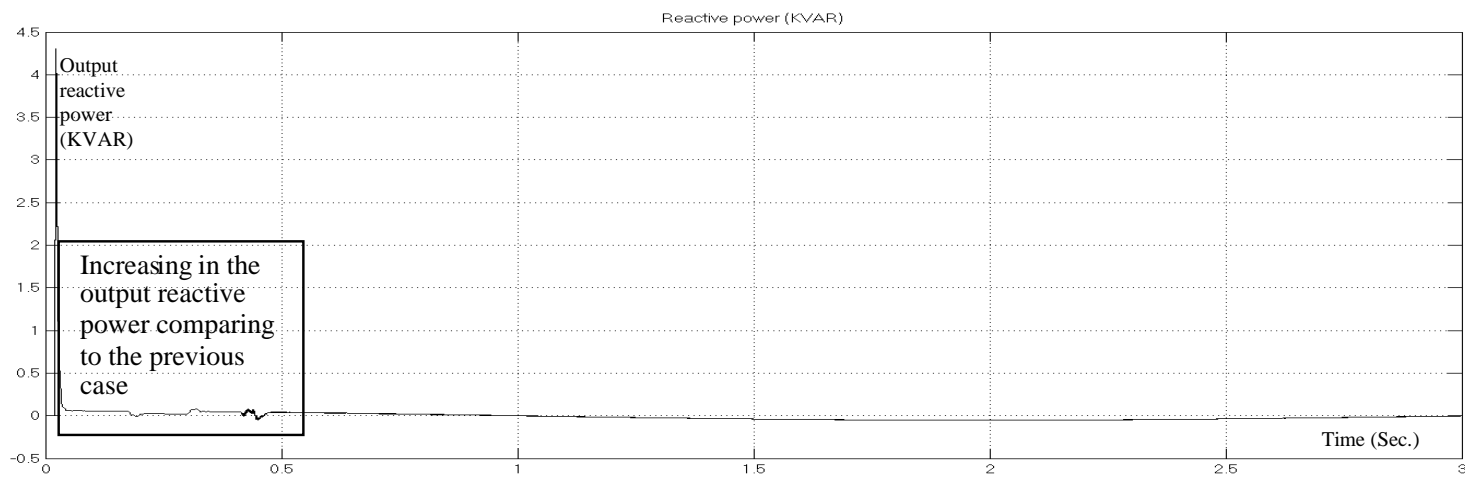

Figure 13. Output reactive power

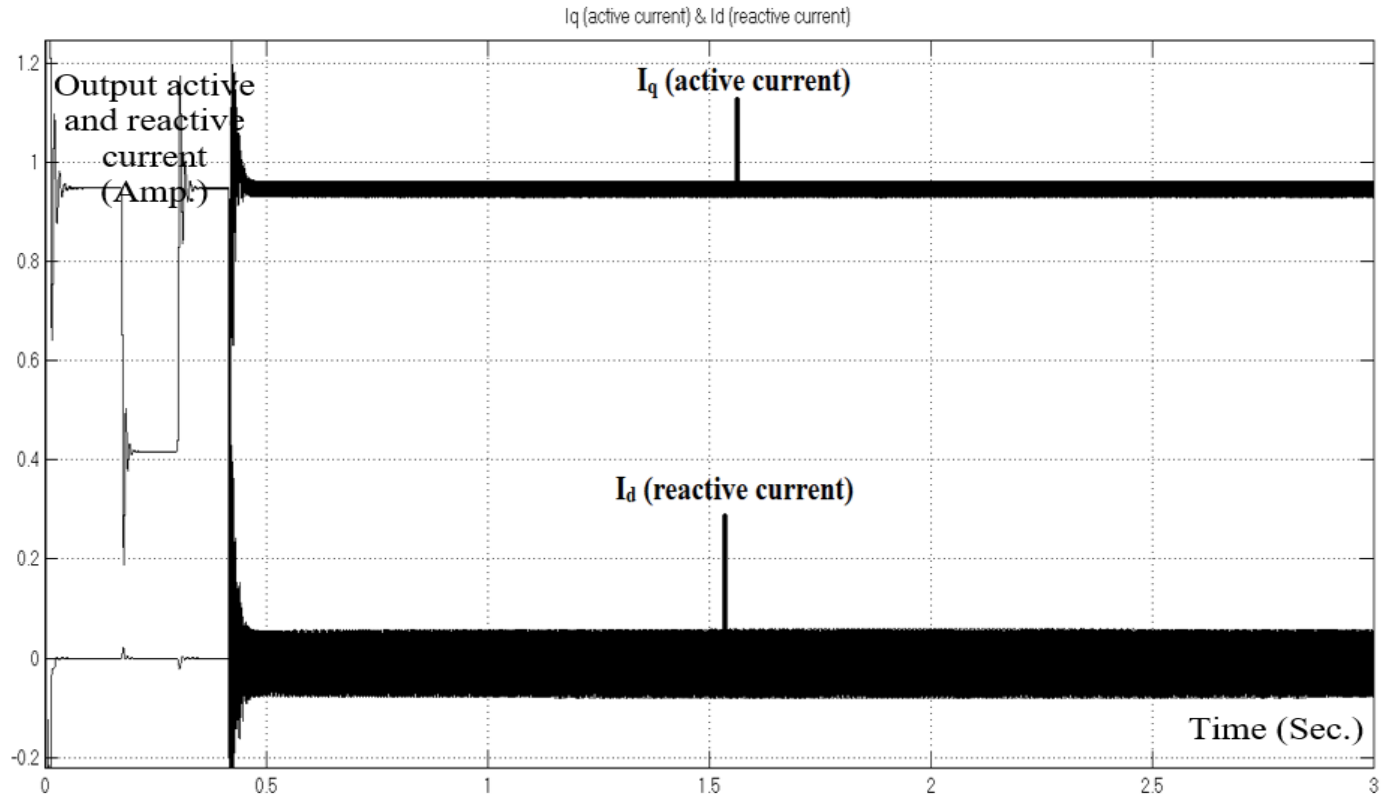

Figure 14. Output $\mathrm{I}_{\mathrm{q}}$ (active current) \& $\mathrm{I}_{\mathrm{d}}$ (reactive current) 


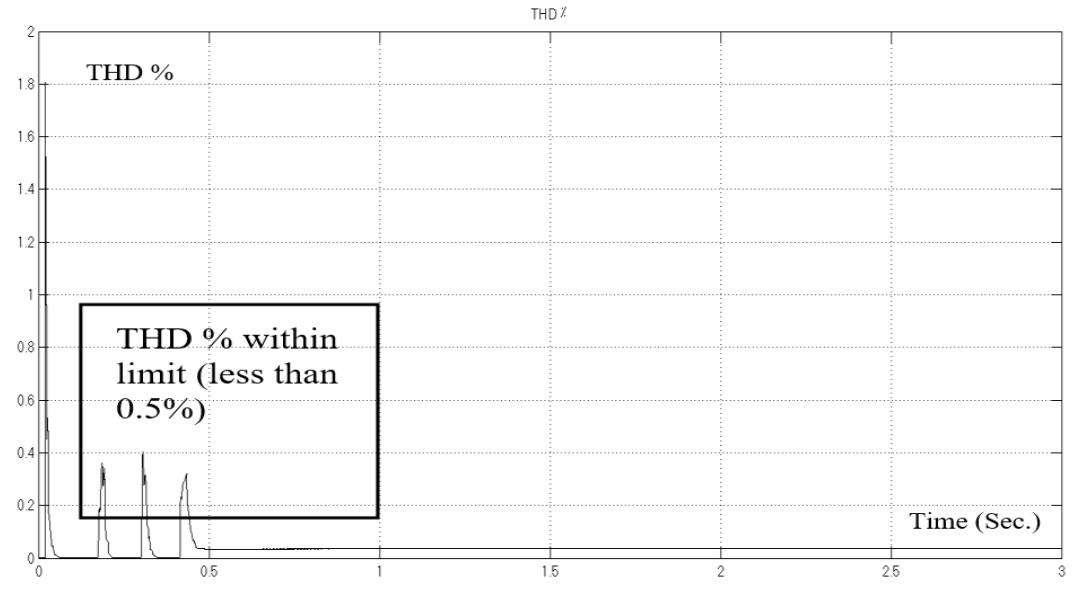

Figure 15. THD \% for current

\subsection{Output results at 3-PH voltage equal 0.5 P.U.}

Figures 16, 17, 18 and 19 shows the output active and reactive power, output active current and reactive current and (THD \% for current) of the on-grid solar system. It was noted that magnitude of the output active power generated from the solar system at maximum value of irradiance is more than the previous cases $6 \mathrm{~kW}$ and the out reactive current $\left(\mathrm{I}_{\mathrm{d}}\right)$ is increase more than the previous case too, which lead to an increase in the output reactive power curve comparing to the previous case, and (THD \% for current) within limit $(0.5 \%)$.

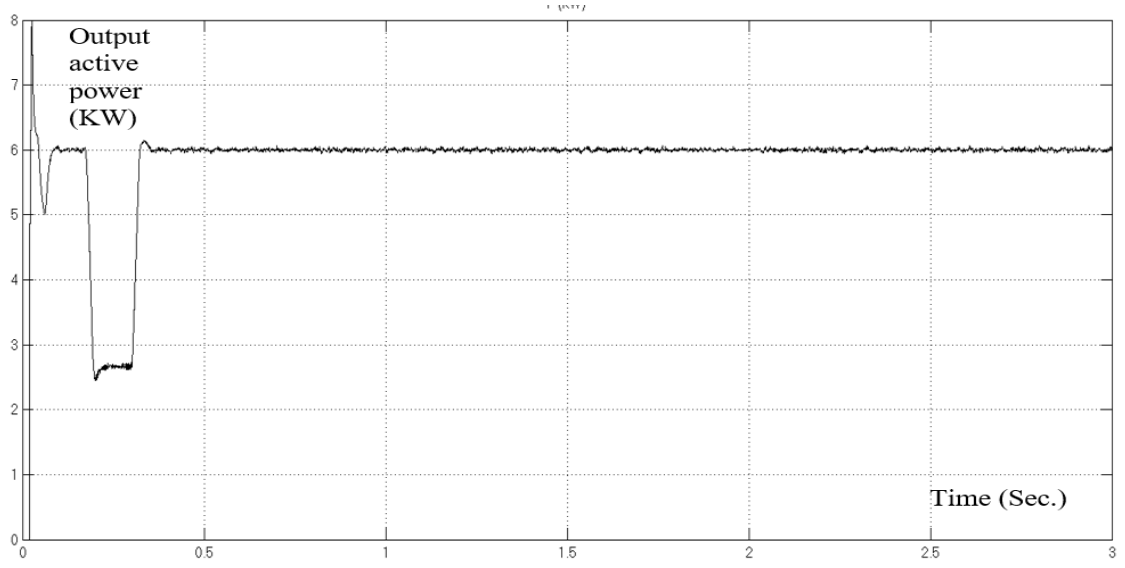

Figure 16. Output active power

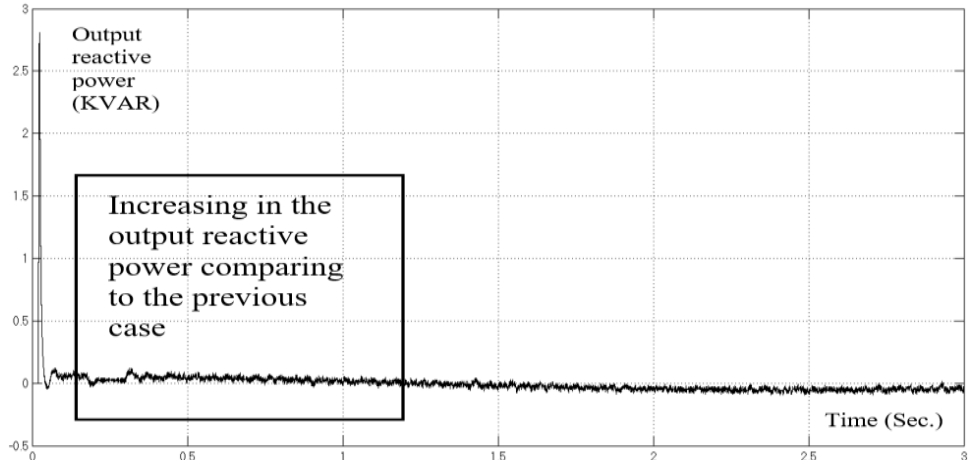

Figure 17. Output reactive power 


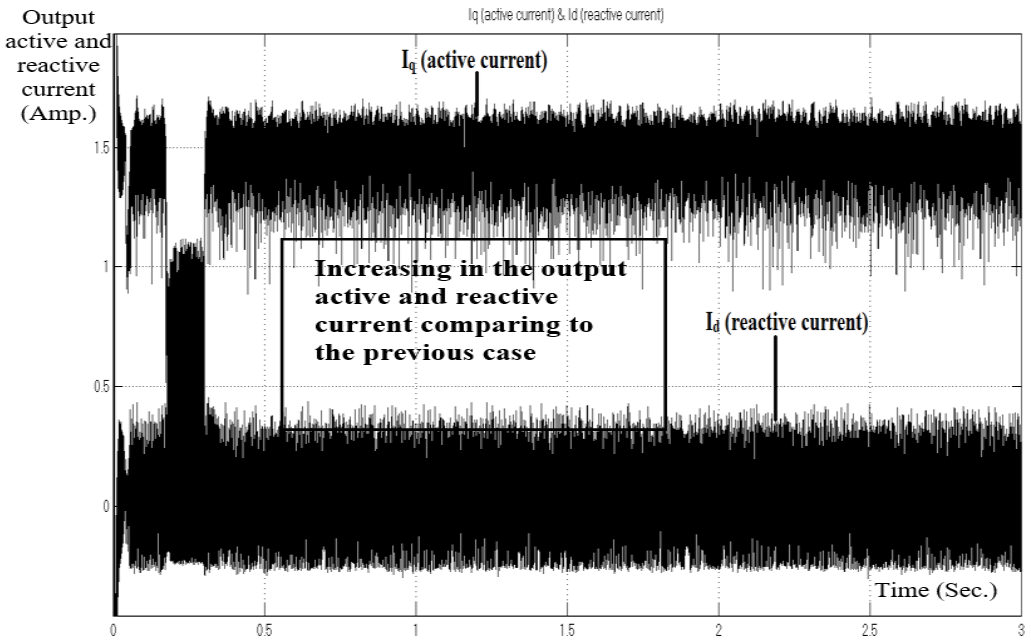

Figure 18. Output $\mathrm{I}_{\mathrm{q}}$ (active current) \& $\mathrm{I}_{\mathrm{d}}$ (reactive current)

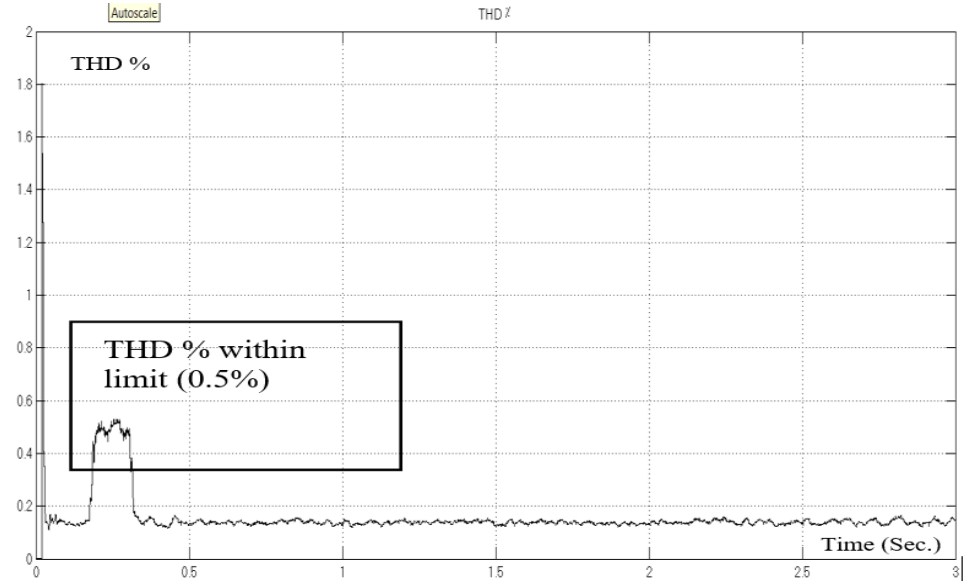

Figure 19. THD \% for current

\subsection{Output results at 3-PH voltage equal 0.47 P.U.}

Figures 20 and 21 shows the output active power and (THD \% for current) of the on-grid solar system. It was noted that magnitude of the output active power at maximum value of irradiance decreased to $5.6 \mathrm{~kW}$ and the (THD \% for current) is $(0.6 \%)$, which is more than the acceptable limit.

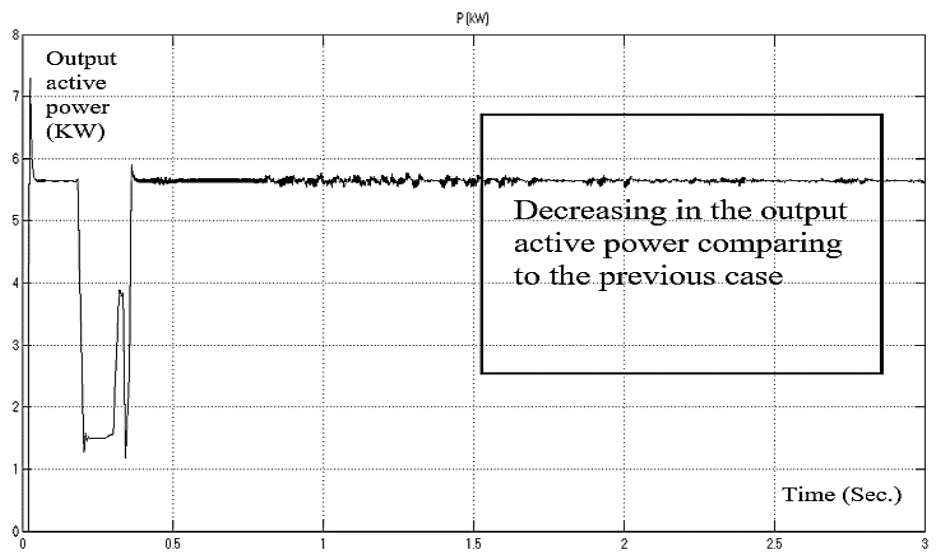

Figure 20. Output active power 


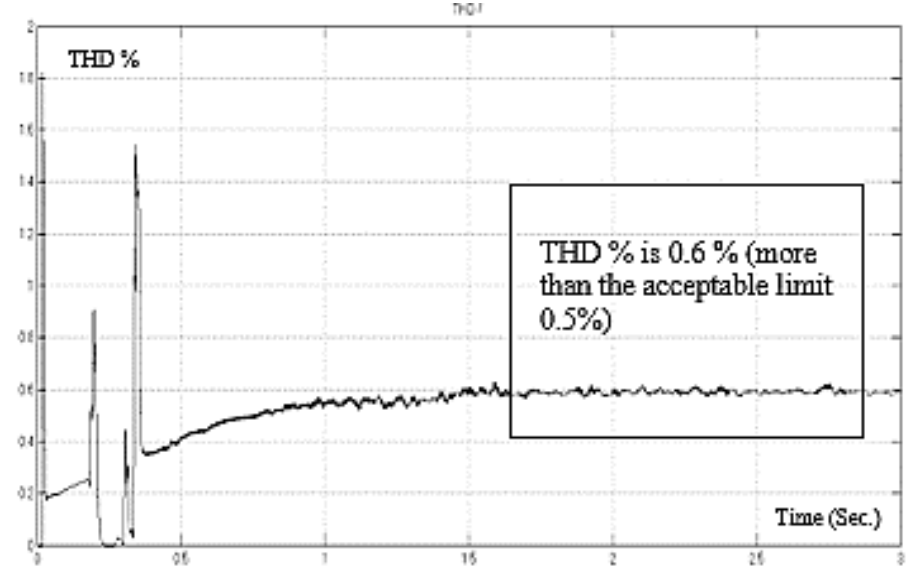

Figure 21. THD \% for current

\subsection{Output result at 3-PH voltage equal 1P.U. by using another control method which is proportional} integral - genetic algorithm (PI-GA)

In this section, another control method was applied, which is proportional integral-genetic algorithm (PI-GA), and Table 3 shows the variables used in this control method. As shown in Figure 22, the fitness function of the proportional integral - genetic algorithm (PI-GA) selected to achieve maximum output active power generated from the PV system, where the fitness function is:

$$
\text { Error }=\text { Power } \text { ref }- \text { Power } \mathrm{PV}
$$

where: Power ref $=$ total active power of the PV array, which is $6.1 \mathrm{~kW}$. Power $\mathrm{PV}=$ maximum output active power generated from the PV system. Error is closest value to zero. Figure 23 represents the Flow chart of proportional integral - genetic algorithm control method (PI-GA). Figure 24 presents the output active power of the on-grid solar system.

It was noted that by using (PI-GA), the value of the output active power generated from the solar system at maximum irradiance value is increased to $6.03 \mathrm{~kW}$ (higher than the value which was achieved by using conventional PI controller at 3-PH voltage equal 1P.U).

Table 3. Variables used in the (PI-GA)

\begin{tabular}{cc}
\hline Variables & Magnitude \\
\hline Population & 14 \\
Probability & 0.85 \\
Number of variables & 4 \\
Bits & 8 \\
No. of generations & 6 \\
$\mathrm{~K}_{\mathrm{P}}$ rate of the current regulator & {$[712]$} \\
$\mathrm{K}_{\mathrm{i}}$ rate of the current regulator & {$[23502500]$} \\
$\mathrm{K}_{\mathrm{P}}$ rate of the DC voltage controller & {$\left[\begin{array}{ll}6 & 11\end{array}\right]$} \\
$\mathrm{K}_{\mathrm{i}}$ rate of the DC voltage controller & {$[500900]$} \\
Rate of mutation & 0.08 \\
Power - ref. (reference power) & $6.1 \mathrm{~kW}$ \\
\hline
\end{tabular}

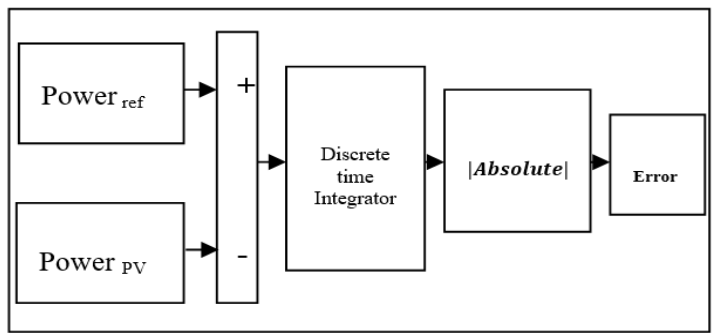

Figure 22. Genetic algorithm fitness function to achieve maximum output active power from the PV system 


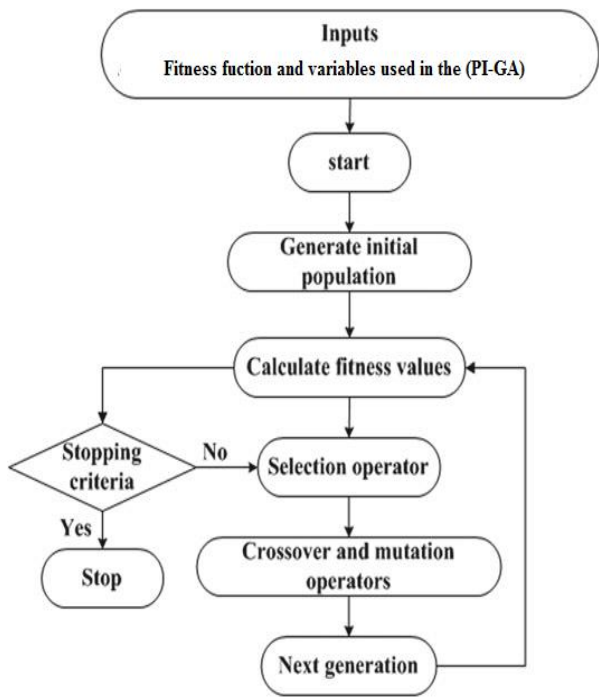

Figure 23. Flow chart of proportional integral-genetic algorithm control method (PI-GA)

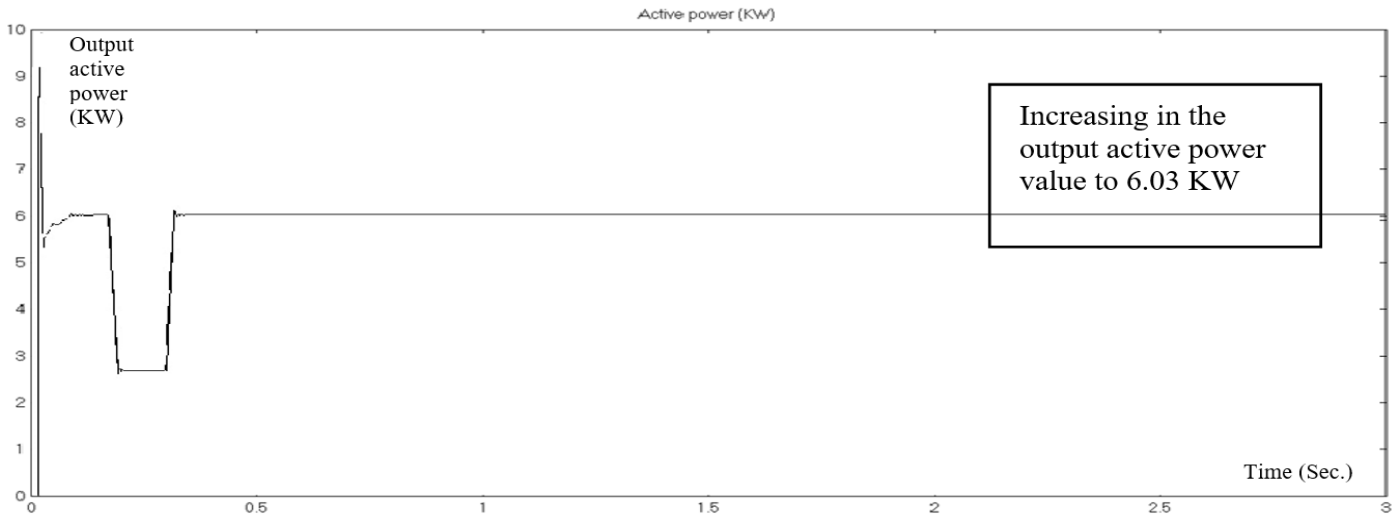

Figure 24. Active power

\subsection{Output result at 3-PH voltage (0.8 P.U.) by using (PI-GA)}

Figure 25 presents the output active power of the on-grid solar system. It was noted that by using (PI-GA), the value of the output active power generated from the solar system at maximum irradiance value is increased to $6.05 \mathrm{~kW}$ (higher than the value which was achieved by using conventional PI controller at 3-PH voltage equal 0.8 P.U.).

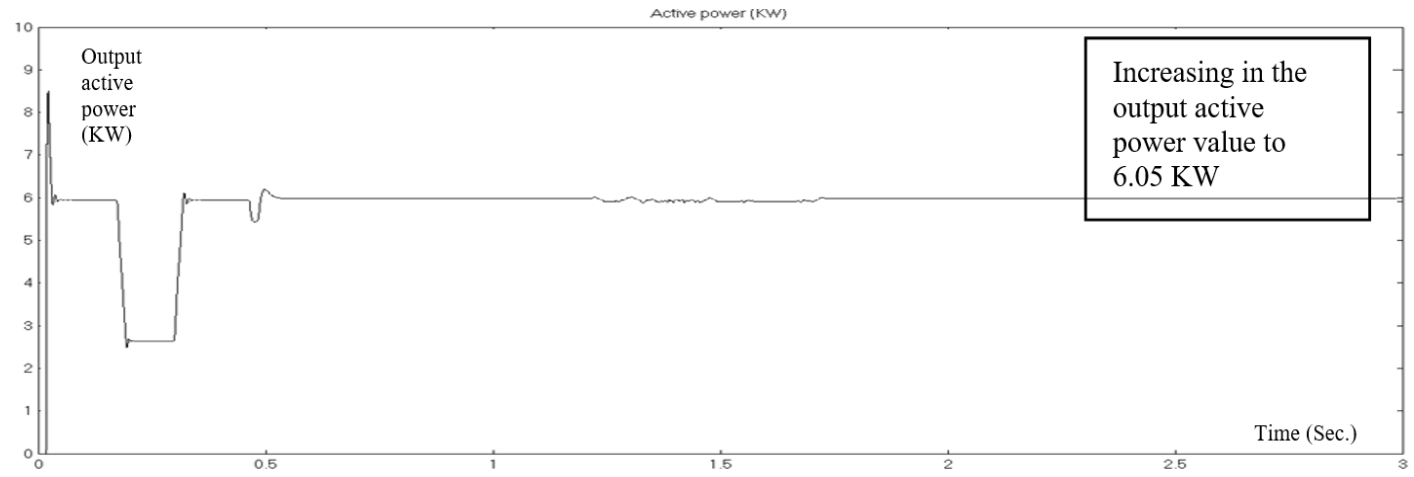

Figure 25. Active power 


\section{CONCLUSION}

This paper presented Impact of grid connected solar energy generation system on low voltage ride through capability, by adjusting the values of the grid voltage which was closely related to the solar system output active and reactive power, active and reactive current and (THD \% for current), with the proposed controller (proportional integral controller) with a model simulated by MATLAB software to achieve the researching point. From the simulation results, it was shown that when the voltage of the grid decreased, according to the low voltage ride through strategy requirement, the solar system should be remaining connected to the grid and operating for a specific time while cases of grid's voltage drop, and supporting the grid with the required reactive current. And supporting the grid also with the maximum output active power generated from it. And this was valid until voltage drop value equal $50 \%$ of the nominal value, when the voltage of the grid decreased than $50 \%$ of the nominal value, the output active power generated from the solar system decreased than its maximum value and the (THD \% for current) increased over than the acceptable range. By using another control method, which was proportional integral - genetic algorithm, the output active power of the solar system was more than the value which was achieved by using conventional PI controller. Future studies could be made by using another control method (fuzzy-neural) and comparing the new results with the achieved results, which were explained in this paper.

\section{REFERENCES}

[1] F. Perera, "Pollution from Fossil-Fuel Combustion is the Leading Environmental Threat to Global Pediatric Health and Equity: Solutions Exist," International journal of environmental research and public health, vol. 15, no. 1, pp. 1-16, 2017, doi: 10.3390/ijerph15010016.

[2] F. Martins, C. Felgueiras, M. Smitkova, and N. Caetano, "Analysis of Fossil Fuel Energy Consumption and Environmental Impacts in European Countries,” Energies, vol. 12, no. 6, pp. 1-11, 2019.

[3] D. Gielen, F. Boshell, D. Saygin, M. D. Bazilian, N. Wagner, and R. Gorini, "The role of renewable energy in the global energy transformation," Energy Strategy Reviews, vol. 24, pp. 38-50, 2019, doi: 10.1016/j.esr.2019.01.006.

[4] F. Oueslati, "Hybrid renewable system based on solar wind and fuel cell energies coupled with diesel engines for Tunisian climate: TRNSYS simulation and economic assessment," International Journal of Green Energy, vol. 18, no. 4, pp. 402-423, 2021, doi: 10.1080/15435075.2020.1865366

[5] F. V. Bekun, F. Emir and S. A. Sarkodie, "Another look at the relationship between energy consumption, carbon dioxide emissions, and economic growth in South Africa," Science of The Total Environment, vol. 655, pp. 759-765, 2019, doi: 10.1016/j.scitotenv.2018.11.271

[6] M. Kumar, K. E. Okedu, A. Tahour, and A. G. Aissaou, "Social, Economic, and Environmental Impacts of Renewable Energy Resources," Wind Solar Hybrid Renewable Energy System, 2020.

[7] Y. Bak, J.-S. Lee, and K.-B. Lee, "Low-Voltage Ride-Through Control Strategy for a Grid-Connected Energy Storage System," Applied Sciences, vol. 8, no. 1, pp. 1-18, 2018, doi: 10.3390/app8010057.

[8] J. Oyekale, M. Petrollese, V. Tola, and G. Cau, "Impacts of Renewable Energy Resources on Effectiveness of Grid-Integrated Systems: Succinct Review of Current Challenges and Potential Solution Strategies," Energies, vol. 13, no. 18, pp. 1-48, 2020.

[9] S. R. Simon, R. L. Riemke, and H. Hoffmann, "Challenges and solution technologies for the integration of variable renewable energy sources - a review," Renewable Energy, Elsevier, vol. 145, pp. 2271-2285, 2020, doi: 10.1016/j.renene.2019.06.147.

[10] S. Al-Ali, I. A. Nassar and H. Weber, "Interconnection of the European ENTSO-E-CE System with the Turkish system: Investigation of the Expected Inter-Area-Oscillations Behaviour," 17th Power Systems Computation Conference, vol. 2, pp. 853$858,2011$.

[11] I. A. Nassar, M. Sh. Seif and M. M. ElAttar, "Improving the voltage quality of abu hummus network in Egypt," International Journal of Electrical and Computer Engineering (IJECE), vol. 10, no. 5, pp. 4458-4468, 2020, doi: 10.11591/ijece.v10i5.pp44584468.

[12] A. Q. Al-Shetwi, M. A. Hannan, K. P. Jern, A. A. Alkahtani, and A. E. PG Abas, "Power Quality Assessment of Grid-Connected PV System in Compliance with the Recent Integration Requirements," Electronics, vol. 9, no. 2, p. 1-22, 2020, doi: 10.3390/electronics9020366.

[13] M. N. I. Sarkar, L. G. Meegahapola and M. Datta, "Reactive Power Management in Renewable Rich Power Grids: A Review of Grid-Codes, Renewable Generators, Support Devices, Control Strategies and Optimization Algorithms," IEEE Access, vol. 6, pp. 41458-41489, 2018, doi: 10.1109/ACCESS.2018.2838563.

[14] B. K. Santhoshi, K. M. Sundaram, S. Padmanaban, J. B. H. Nielsen, and K. K. Prabhakaran, "Critical Review of PV Grid-Tied Inverters," Energies, vol. 12, no. 10, pp. 1-26, 2019, doi: 10.3390/en12101921.

[15] A. Benali, M. Khiat, T. Allaoui and M. Denaï, "Power Quality Improvement and Low Voltage Ride Through Capability in Hybrid Wind-PV Farms Grid-Connected Using Dynamic Voltage Restorer," IEEE Access, vol. 6, pp. 68634-68648, 2018, doi: 10.1109/ACCESS.2018.2878493.

[16] P. Mukherjee and V. V. Rao, "Superconducting magnetic energy storage for stabilizing grid integrated with wind power generation systems," Journal of Modern Power Systems and Clean Energy, vol. 7, no. 2, pp. 400-411, 2019, doi: 10.1007/s40565018-0460-y.

[17] A. Q. Al-Shetwi, M. Z. Sujod, and N. L. Ramli, "A review of the fault ride through requirements in different grid codes concerning penetration of PV system to the electric power network," ARPN Journal of Engineering and Applied Sciences, vol. 10, no. 21, pp. 9906-9912, 2015.

[18] S. A. Ansari, A. R. Mizani, S. Ashouri, and J. S. Moghani, "Fault Ride-Through Capability Enhancement for Microinverter Applications," Journal of Renewable Energy, vol. 2019, pp. 1-13, 2019, doi: 10.1155/2019/1036156.

[19] W. Fan, Z. Wu, X. Dou, M. Hu, J. Wei, and Zhenyu Lv, "Design of a Microgrid with Low-Voltage Ride-Through Capability and Simulation Experiment," Journal of Applied Mathematics, vol. 2014, pp. 1-9, 2014, doi: 10.1155/2014/324527.

[20] Y. Yang, F. Blaabjerg, and H. Wang, "Low-Voltage Ride-Through of Single-Phase Transformerless Photovoltaic Inverters," IEEE Transactions on Industry Applications, vol. 50, no. 3, pp. 1942-1952, 2014, doi: 10.1109/TIA.2013.2282966. 
[21] X. Wang, Z. Yang, B. Fan, and W. Xu, "Control Strategy of Three-Phase Photovoltaic Inverter under Low-Voltage Ride-Through Condition," Mathematical Problems in Engineering, vol. 2015, pp. 1-23, 2015, doi: 10.1155/2015/790584.

[22] L. Wang, T. Qiao, B. Zhao, X. Zeng, and Q. Yuan, "Modeling and Parameter Optimization of Grid-Connected Photovoltaic Systems Considering the Low Voltage Ride-through Control," Energies, vol. 13, no. 15, pp. 1-23, 2020, doi: 10.3390/en13153972.

[23] S. Seme, B. Štumberger, M. Hadžiselimović, and K. Sredenšek, "Solar Photovoltaic Tracking Systems for Electricity Generation: A Review," Energies, vol. 13, no. 16, pp. 1-24, 2020, doi: 10.3390/en13164224.

[24] D. Ismail, A. El Fadili, D. El Kasmi and M. Stitou, "Evaluation of the LVRT Requirement for Wind Farms specified in the Moroccan Grid Code," Renewable Energies, Power Systems \& Green Inclusive Economy (REPS-GIE), 2018, pp. 1-5, doi: 10.1109/REPSGIE.2018.8488869.

[25] H. Chen, C. Lee, P. Cheng, R. Teodorescu and F. Blaabjerg, "A Low-Voltage Ride-Through Technique for Grid-Connected Converters with Reduced Power Transistors Stress," IEEE Transactions on Power Electronics, vol. 31, no. 12, pp. 8562-8571, 2016, doi: 10.1109/TPEL.2016.2522511.

[26] I. Nassar, I. Elsayed and M. Abdella, "Optimization and Stability Analysis of Offshore Hybrid Renewable Energy Systems," 21st International Middle East Power Systems Conference (MEPCON), 2019, pp. 583-588, doi: 10.1109/MEPCON47431.2019.9007963.

[27] S. Mashaly and M. H. Abdallah, "Low voltage ride through and fault ride through capability of $40 \mathrm{~kW}$ PV model grid connected," Saudi Arabia Smart Grid (SASG), 2016, pp. 1-6, doi: 10.1109/SASG.2016.7849684.

\section{BIOGRAPHIES OF AUTHORS}
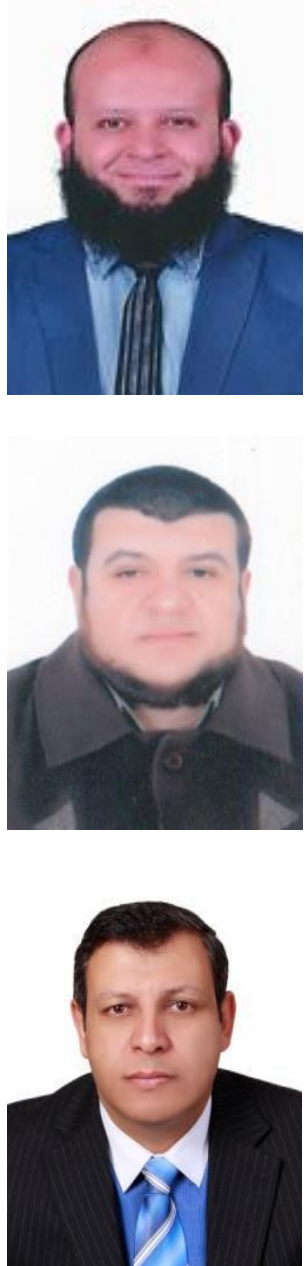

Mohammad Ahmad Shawqi (iD) 80 SC P received the B.Sc. (2004) in Electrical Engineering from Ain Shams University. Since (2004), he has been at the Egyptian Ministry of Electricity and Renewable Energy (MoERE). During this period, he worked at Kuwait Ministry of Electricity and Water (MEW Kuwait) for 2 years, since (2020) he has been approved as new and renewable energy consultant from the Egyptian Engineers Syndicate. Currently he is Head of Department of African Affairs and Nile Basin Department at the Egyptian Ministry of Electricity and Renewable Energy, Cairo, Egypt. He can be contacted at email: wild_shakshak@yahoo.com.

Mokhtar Hussien Abdallah (iD) 8d sc P B.Sc. Electrical Engineering (Ain Shams University) 2003, Master degree (Cairo University) 2007, Doctorate degree " (Al-Azhar University) 2011. working as a M.V testing engineer (Egypt), senior design engineer (Oman) and current position in state developing performance, Ministry Of Electricity And Renewable Energy. He can be contacted at email: moktar_hussien@yahoo.com

Ibrahim Nassar (D) II SC P received the B.Sc. (1999) \&M.Sc. (2004) degrees in Electrical Engineering from Al-Azhar University. Since (2001), he has been at faculty of Engineering; Al-Azhar University. He received his PhD in Rostock University, Germany (2011). Currently he is Head of Department of Electrical Engineering, Faculty of Engineering, Al-Azhar University, Cairo, Egypt. He can be contacted at email: ibrahim.nassar@azhar.edu.eg 